\title{
Connessioni tra museo/archivi e città: strategie digitali per la valorizzazione e comunicazione del fondo Fichera del Museo della Rappresentazione
}

\author{
Mariateresa Galizia \\ Graziana D'Agostino \\ Raissa Garozzo \\ Federico Mario La Russa
}

Abstract

Lo studio propone la sperimentazione condotta presso il Museo della Rappresentazione del Dicar, struttura appartenente al Sistema Museale dell'Ateneo di Catania. II museo conserva ed espone gli archivi dei progetti di architetti locali che hanno contribuito a tracciare l'identità architettonico-urbanistica del territorio. Esso si pone come archivio aperto agli studiosi e, allo stesso tempo, museo che espone singoli pezzi dei fondi posseduti, materiale documentale altamente tecnico che conserva la memoria dei luoghi. La natura dei documenti sollecita la necessità di dotarsi di nuovi strumenti e strategie per veicolare il patrimonio documentale ed esplicitarlo a un'utenza anche non specialistica. Per questi motivi il MuRa oggi costituisce un luogo di sperimentazione e ricerca di nuovi linguaggi e forme di comunicazione del patrimonio culturale, oltre ad assumere il ruolo educativo di affezione e identificazione ai luoghi. La sperimentazione condotta su alcuni progetti del fondo dell'architetto catanese Francesco Fichera (1 88 I-1950), ha prodotto modelli digitali ottenuti attraverso l'integrazione e/o comparazione delle informazioni di progetto e del costruito, del disegno di archivio e del rilievo. Le elaborazioni digitali prodotte consentono, inoltre, la fruizione virtuale e immersiva delle architetture esposte al MuRa, favorendo l'intercettazione di una fascia di utenza allargata, quella dei visitatori del museo. Inoltre, il materiale tecnico elaborato costituisce un arricchimento dei documenti in possesso, anch'esso da catalogare e archiviare.

Parole chiave

documentazione, riproduzione, virtualità, rilievo digitale, accessibilità.
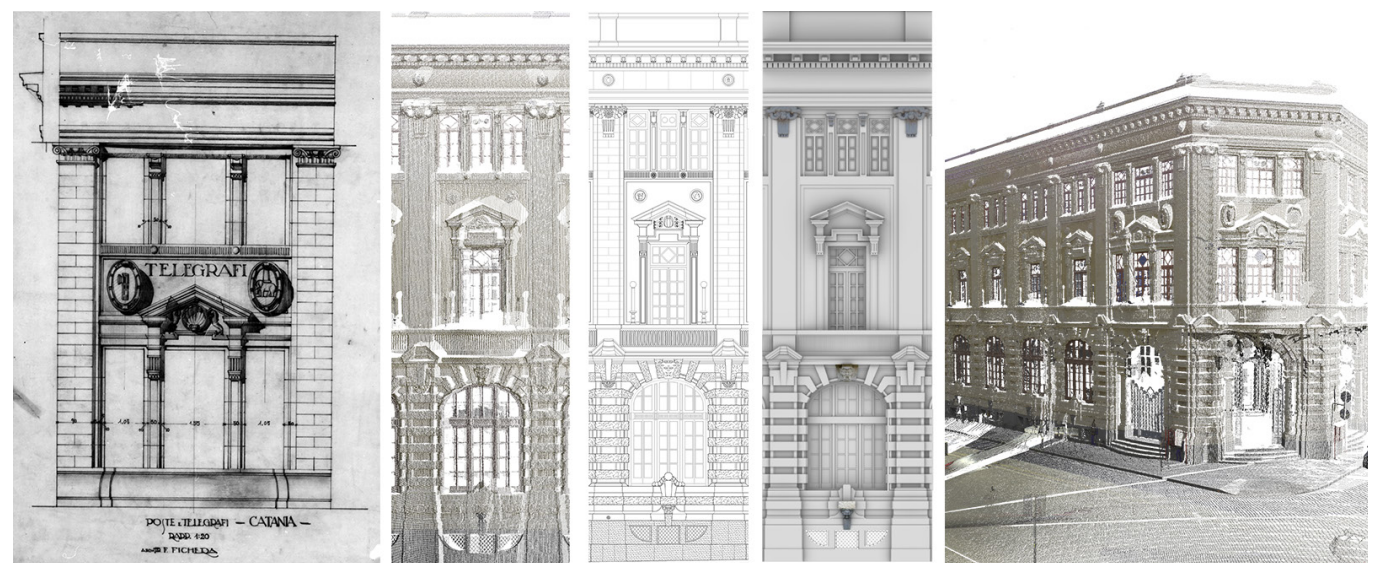


\section{Introduzione}

Nel documento sui musei, pubblicato dall'Unesco nel 1984, si fa riferimento alla salvaguardia della documentazione originale del patrimonio culturale, e quindi ai musei di archivi. Tra questi il patrimonio iconografico dei progetti di architettura, il cui interesse darà l'avvio alla nascita di istituzioni rivolte allo studio dei documenti originali per la conservazione della memoria storica dei luoghi [I]. L'Italia risponde attivamente e con interesse al tema della salvaguardia del patrimonio storico-archivistico, dando avvio a programmi di raccolta, conservazione e divulgazione di archivi [2]. Nascono centri e fondazioni private oltre a biblioteche e università che diventano luoghi di conservazione e consultazione di documenti. Tra questi, I'Istituto Dipartimentale di Architettura e Urbanistica della ex Facoltà di Ingegneria di Catania, attuale Dipartimento di Ingegneria Civile e Architettura, al quale viene donato nel 1976, dagli eredi dell'architetto catanese Francesco Fichera, l'archivio progetti. La donazione conta circa 1600 disegni originali, eseguiti con tecniche varie - matita, con pastelli, a china, ad acquarello - o in copia eliografica. Con il progetto Catania-Lecce del 1997 il fondo, insieme ad altro materiale, viene trasferito e custodito presso il Museo della Rappresentazione, afferente al dipartimento e dal 2015 facente parte del Sistema Museale dell'Ateneo. II museo si pone sia come archivio aperto agli studiosi sia come luogo in cui viene esposto il materiale documentale, altamente tecnico, dei fondi posseduti. La mission del Museo, oltre la tradizionale conservazione, salvaguardia e fruizione del proprio patrimonio archivistico, è l'impegno all'educazione culturale e al rispetto dei luoghi attraverso la ricerca di nuove forme comunicative del patrimonio culturale.

L'articolo presenta i risultati della sperimentazione condotta sulla comunicazione museale di tre progetti di architetture pubbliche, realizzate a Catania dall'architetto Francesco Fichera nei primi anni del '900. L'obiettivo è quello di comunicare in modo chiaro ed elementare, non solo agli addetti ai lavori ma anche al vasto pubblico, la poetica del progettista che opera tra tradizione e innovazione. Di fatto, nell'esposizione museale dei progetti, l'incompletezza della documentazione di archivio o la parzialità degli elaborati esposti, costituisce un limite alla comprensione delle caratteristiche stilistico-formali e geometrico-spaziali delle opere. Al fine di rendere chiara e immediata la lettura, sono stati creati modelli 3D per la fruizione virtuale delle architetture esposte, frutto di un processo di integrazione dei dati di progetto e di rilievo digitale.

\section{Metodologia}

La metodologia adottata ha previsto la sperimentazione di strategie innovative di documentazione e di comunicazione finalizzate alla comprensione e narrazione, virtuale ed immersiva, dei progetti di archivio F. Fichera, selezionando alcuni ambienti delle architetture pubbliche realizzate, oltre che all'incremento e all'implementazione della documentazione grafica esistente.

Si individuano tre macro-fasi:

- documentazione: lettura ed analisi critica dei disegni di progetto conservati in archivio, per comprendere le carenze di materiale grafico, le eventuali varianti in corso d'opera e per indagare il percorso ideativo dell'iter progettuale;

- riproduzione: rilievo digitale integrato (Laser Scanner e Structure from Motion - SfM) dei casi studio scelti al fine di ottenere sia ricostruzioni tridimensionali che elaborazioni bidimensionali aggiornate;

- virtualità: uso di tecnologie VR low-cost per la valorizzazione e trasmissione della memoria e dell'identità storica del patrimonio culturale.

In primo luogo, si è condotta l'indagine storico-documentale, consultando il materiale di archivio, quali le schede di catalogazione esistenti, che rispondono alle prescrizioni dell'ICCD sulla catalogazione dei BB.CC. e le tavole progettuali presenti sia in formato cartaceo che digitale, in modo da effettuare una lettura critica del progetto rispetto all'edificio realizzato. Ove il materiale risultava carente, si è proceduto alla campagna di rilievo tramite laser scan- 
ner, modello RTC360 della Leica Geosystem, e rilievo tramite metodologia SfM, utilizzando una macchina fotografica Canon Eos I200D, in relazione alle caratteristiche geometrico/ spaziali degli edifici. II materiale prodotto consente agli utenti che visitano le sale del Museo, all'interno delle quali sono esposti i disegni d'archivio dei progetti, di fruire virtualmente alcuni ambienti delle architetture indagate.

Per coinvolgere gli utenti all'interno di una visita virtuale conoscitiva ed interattiva, sono state testate due diverse tecniche: una in cui l'utente, accedendo alla piattaforma online Sketchfab ed utilizzando visualizzatori low-cost di realtà virtuale, si trova proiettato dentro una nuvola di punti all'interno della quale può muoversi liberamente e percepire la spazialità di luoghi spesso inaccessibili al pubblico [Santagati 20 I8, pp. 737-746]; '’altra attraverso l'uso di immagini sferiche [Ferrari 20 17, pp. 27, 28; Scandurra 2018, pp. I037- I044]. Questo approccio garantisce una più semplice e immediata esperienza immersiva, poiché i contenuti raster richiedono meno risorse computazionali e sono facili da usare sui dispositivi mobili. II visitatore ha, allo stesso tempo, la possibilità di visualizzare semplicemente la restituzione 3D sul proprio dispositivo mobile.

\section{Fichera e gli edifici pubblici: tra tradizione e innovazione}

\section{Francesco Fichera (Catania, I881-1950)}

Francesco Fichera è uno dei principali protagonisti della cultura architettonica siciliana della prima metà del Novecento. Laureato presso la Regia Scuola di Applicazione di Roma nel 1905, si diploma in Architettura presso l'Accademia di Belle Arti di Palermo e consegue la libera docenza nel 1909. Dal 1913 ricopre la cattedra di Disegno d'ornato e di Architettura elementare presso il primo nucleo della Facoltà di Ingegneria di Catania. Considerato uno dei più grandi protagonisti del Modernismo, realizza numerose opere in ambito residenziale e pubblico [Guarrera 2017]. Sperimenta soluzioni formali che spaziano dall'Eclettismo al Liberty, al Déco, al Razionalismo. Nelle architetture a carattere pubblico, nel rispetto dei principi del tempo secondo cui l'architettura statale dovesse assumere un ruolo simbolico per la città ed espressivo di un regime politico volto alla ricerca di vasti consensi, il Fichera opera una mediazione tra l'esigenza di uno stile rappresentativo e la nuova cultura, riproponendo stilemi classici unitamente a nuove soluzioni compositive [Galizia 2002]. Tra le opere pubbliche che descrivono l'evoluzione di pensiero dell'architetto, sono state indagate tre architetture realizzate a Catania: la palazzina della Società Elettrica, il Palazzo delle Poste, I'Istituto Tecnico Commerciale De Felice (fig. I).

Fig. I. A sinistra la Palazzina Enel, al centro il Palazzo delle Poste, a destra Istituto "De Felice".
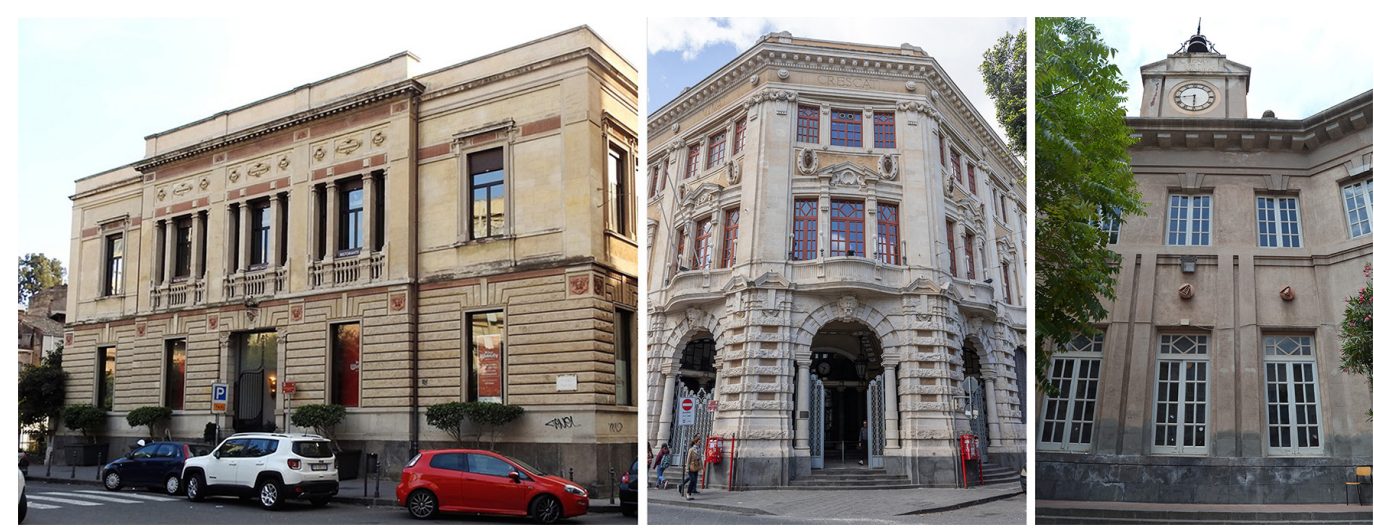

Palazzina della Società Elettrica (19/3)

La Palazzina per la fornitura di energia elettrica è un edificio lineare e compatto su tre livelli, caratterizzato da una sobria e innovativa rivisitazione degli stilemi dell'Art Déco. L'impaginato del prospetto, di ispirazione secessionista, è ritmato da lesene e marcapiani lievemente aggettanti, dall'alternarsi cromatico di formelle decorative in cotto recanti il simbolo della Trinacria su intonaco chiaro e dalle fasce orizzontali di intonaco grezzo a bugne, che segna- 
Fig. 2. A sinistra, nuvola di punti dell'esterno; a destra nuvola di punti dello scalone monumentale.
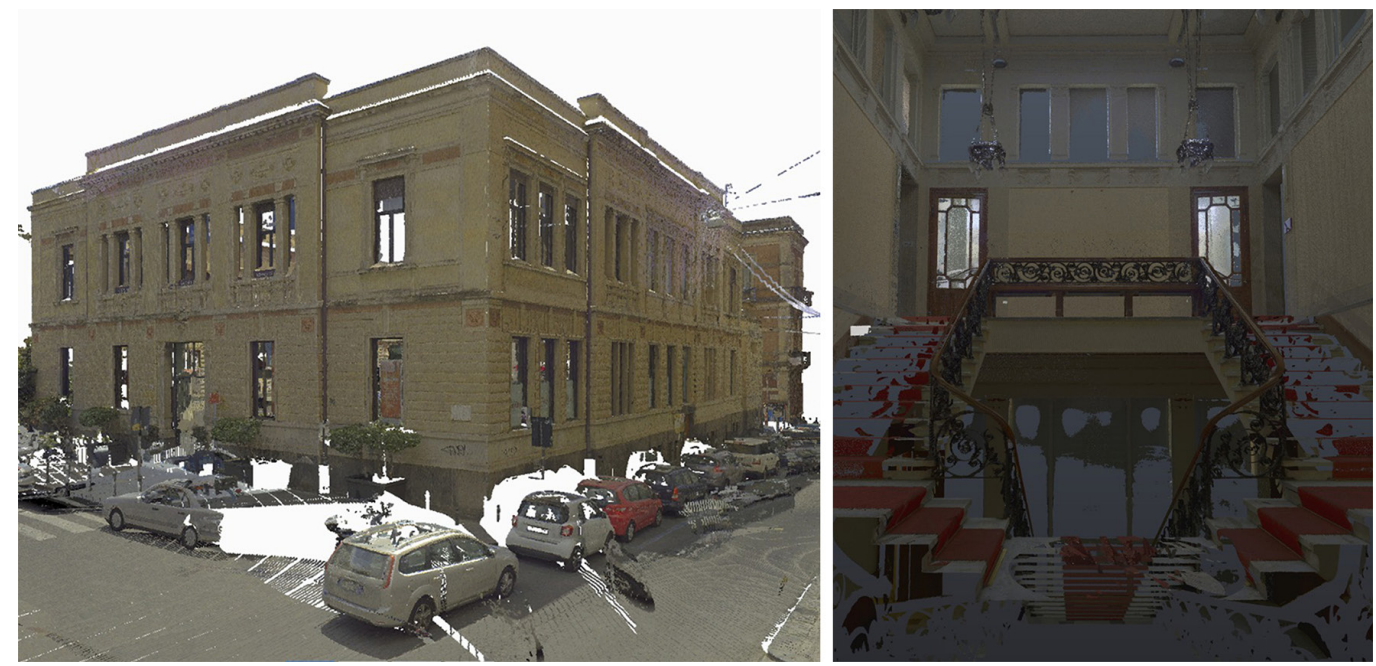

no i paramenti murari al piano terra. L'edificio si presenta funzionalmente articolato in tre livelli: il seminterrato, che nella configurazione originale ospitava i locali tecnici, il piano terra a servizio del pubblico e l'ultimo livello per l'amministrazione. L'atrio d'ingresso, ortogonale rispetto al fronte stradale, conduce al grande salone centrale, illuminato naturalmente da un lucernario in ferro battuto. Fulcro dell'intero edificio è il monumentale scalone a tenaglia ornato da una pregevole ringhiera in ghisa con spirali e motivi Liberty. La palazzina ha subito nel tempo diverse modifiche, dovute principalmente al cambio di destinazione d'uso: l'ingresso e il salone sono attualmente un'area commerciale, il resto dell'edificio è privato. Per separare gli spazi è stato apposto un divisorio che nasconde lo scalone monumentale, non consentendo una visione d'insieme dell'architettura.

La verifica degli elaborati custoditi presso l'archivio Fichera e il confronto di questi con lo stato di fatto, ha richiesto la creazione di contenuti integrativi attuali. È stato possibile individuare, infatti, alcune variazioni dell'idea progettuale originale, come la differente soluzione formale delle bucature lungo il prospetto principale (fig. 3). Per supplire all'assenza di
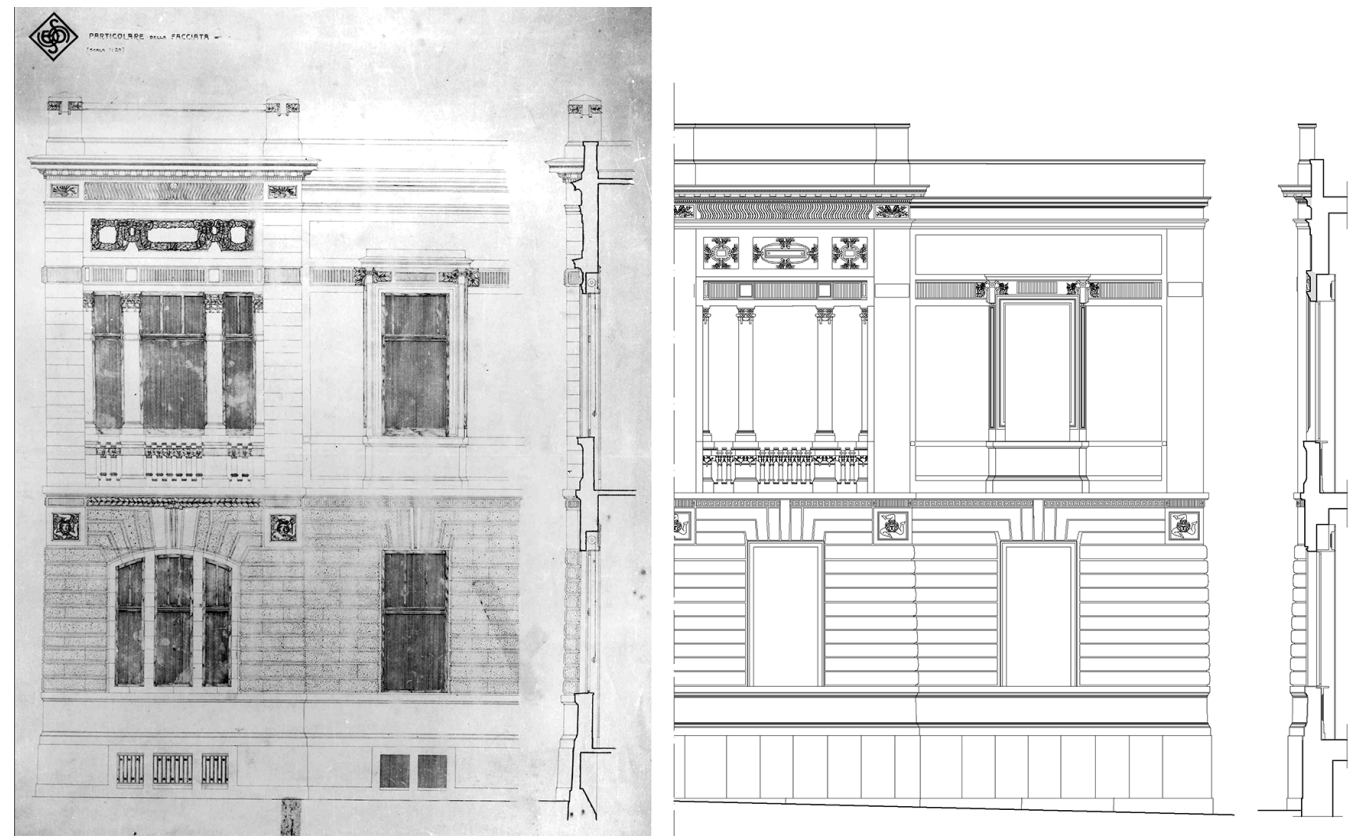
Fig. 4. Documenti del Palazzo delle Poste (Archivio Fichera), da sinistra a destra: pianta scalone in scala $1: 200 \mathrm{e}$ l:20, dettaglio costruttivo parapetto. documentazione relativa all'emblematico scalone monumentale e consentire una visione d'insieme degli spazi non pienamente fruibili dell'edificio, l'ingresso secondario, lo scalone, l'area esterna in corrispondenza del lucernario ed i prospetti sono stati acquisiti tridimensionalmente tramite metodologia laser scanning (fig. 2). La fotogrammetria multimmagine è stata, invece, utilizzata per il rilievo di alcuni arredi d'epoca. Tale approccio ha permesso la creazione di elaborati bidimensionali e tridimensionali allo scopo di ricreare una documentazione completa del manufatto e comunicare l'idea progettuale ai non addetti ai lavori, anche attraverso una possibile fruizione virtuale dei luoghi.
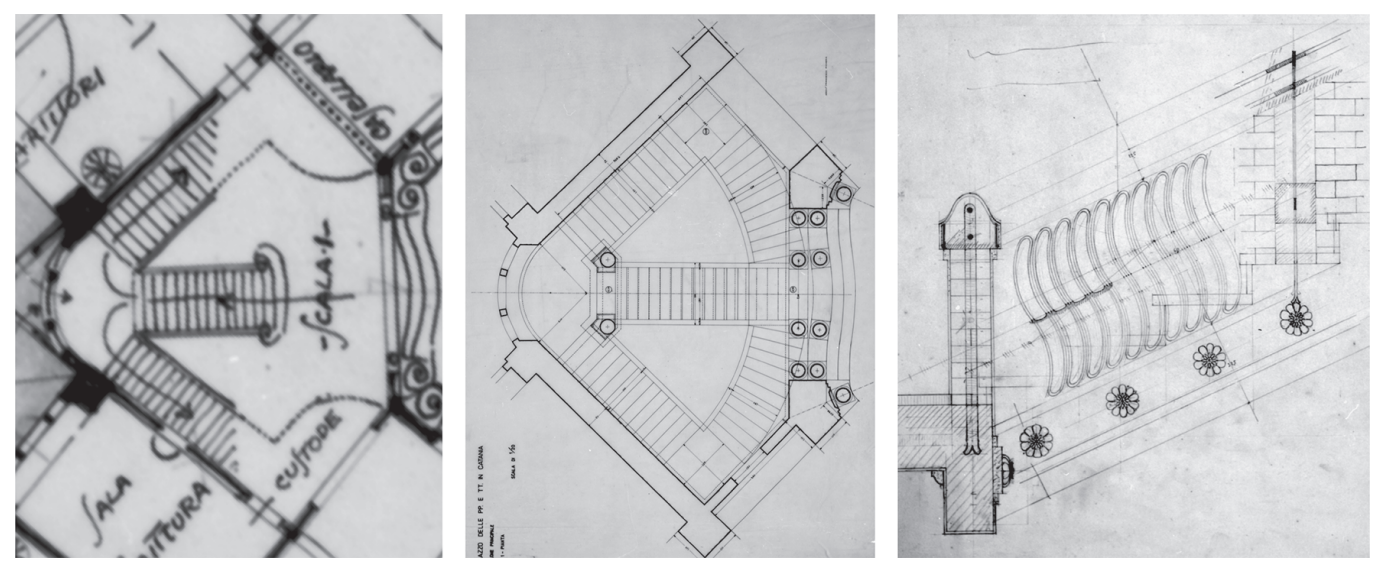

Palazzo delle Poste (1919)

I| Palazzo delle Poste, realizzato nel 1929, si articola su tre livelli e si contraddistingue per via dei prospetti in pietra lavica e di Ispica che definiscono campate convesse scandite da paraste di ordine gigante. L'edificio occupa un lotto di testata prospiciente su via Etnea, via della Posta e via Sant'Euplio. II suo involucro barocco si accompagnano a soluzioni moderniste nei percorsi interni.

In asse con l'ingresso principale si accede allo scalone per il pubblico, interessante per la pianta triangolare e lo sviluppo delle rampe. Esso presenta manufatti unici come le due colonne che sostengono i pianerottoli intermedi in stile liberty. Lo scalone ad oggi non risulta accessibile al pubblico.

I documenti nell'archivio Fichera circa lo scalone consistono nelle piante in scala 1:200 (relativi alla prima ipotesi progettuale) ed i successivi disegni esecutivi al 20 (una pianta ed una sezione costruttiva del parapetto) (fig. 4). L'assenza di alzati e/o sezioni significativi e l'inaccessibilità di questo ambiente hanno spinto dunque ad adottare la metodologia del rilievo architettonico allo scopo di verifica (rispetto ai documenti) e di divulgazione.

II rilievo è stato condotto integrando metodologie dirette e strumentali (laser scanning). I prodotti sono stati confrontati con i disegni esecutivi disponibili indagando possibili variazioni in corso d'opera. Si è passati alla restituzione di una sezione verticale per poter rappresentare (in coerenza coi documenti d'archivio) lo sviluppo dello scalone (fig. 5). La particolare spazialità dovuta alla rampa di arrivo ai pianerottoli (ad andamento curvilineo) e la plasticità delle decorazioni, difficilmente restituiscono elementi in vera forma rendendo di difficile lettura lo spazio ed il linguaggio architettonico realizzato dal progettista.

Per tale ragione, la nuvola di punti ottenuta dal rilievo strumentale è stata importata in CloudCompare per un'ottimizzazione funzionale all'esplorazione online del modello in realtà virtuale. Ciò è possibile grazie alla piattaforma online Sketchfab.com, la quale consente facilmente di incorporare contenuti 3D su siti web e altre piattaforme digitali. Tale portale è già utilizzato da musei, come il British Museum. Altre soluzioni quali 3DHop ed Europeana sono state valutate per sviluppi futuri in relazione a contenuti più complessi e specifici. Attraverso Sketchfab.com è quindi possibile esplorare il modello in realtà virtuale (fig. 6) sia attraverso visori VR low cost (come Google Cardboard) sia con visori più performanti (come Oculus Rift). 
Fig. 5. Da sinistra a destra sezione verticale dello scalone lungo l'asse principale e foto dell'ingresso e delle colonne decorate.
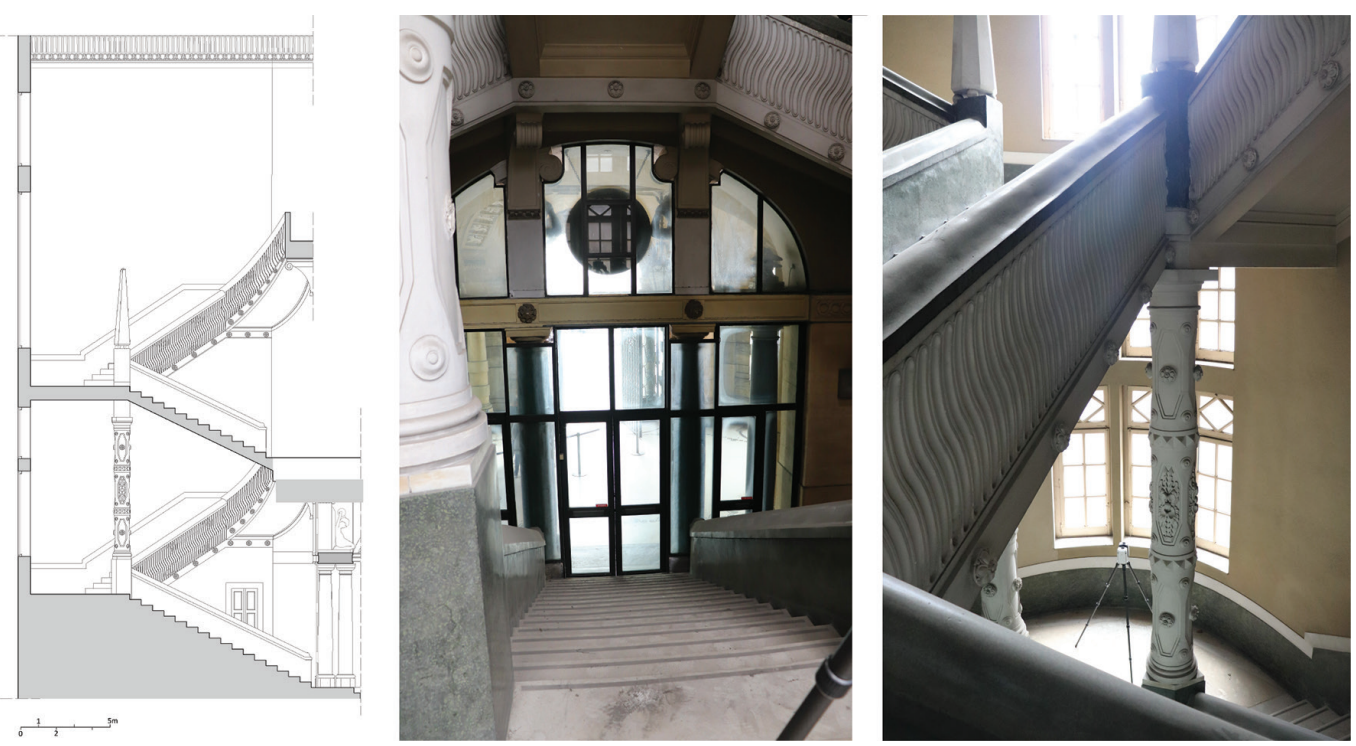

Fig. 6. Interfaccia settaggi VR sulla piattaforma onlne Sketchfab e visualizzazione VR da dispositivo mobile.

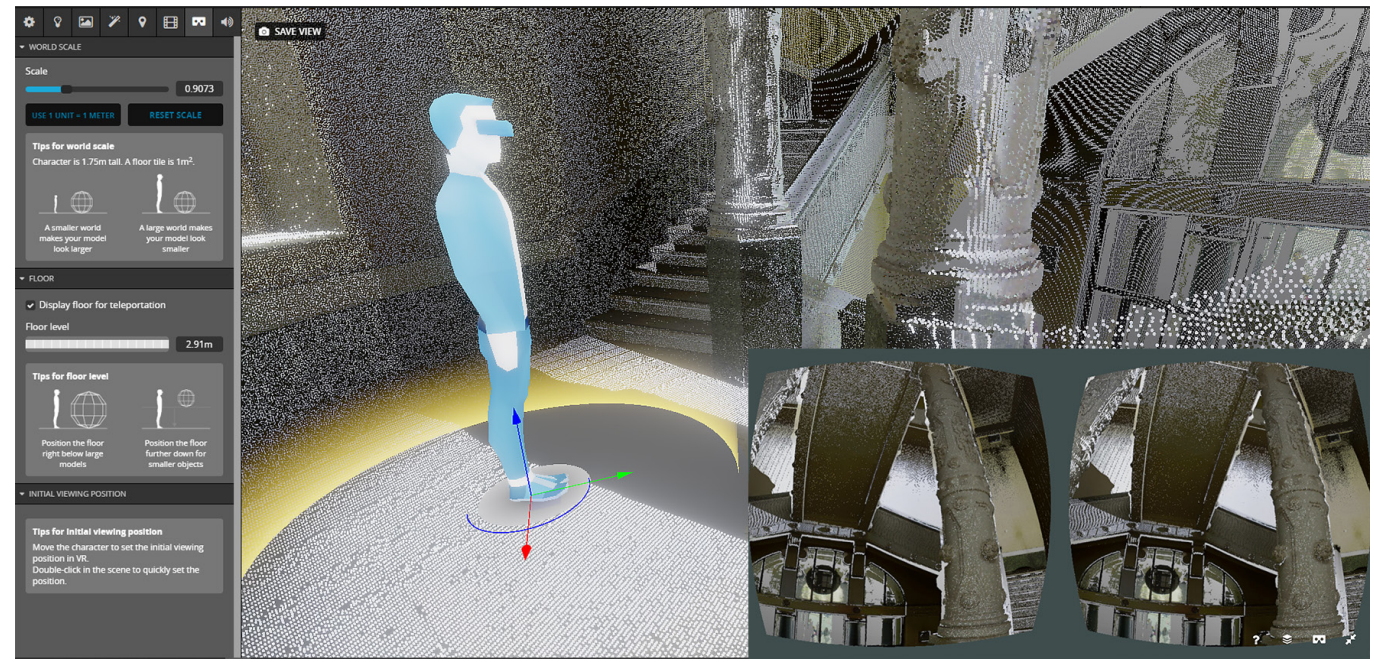

Istituto Tecnico Commerciale De Felice (1926)

Le soluzioni architettoniche adottate nel progetto dell'istituto scolastico sintetizzano i temi ricorrenti del modus operandi dell'architetto catanese. Se da un lato le aperture tripartite delle facciate esterne ricordano le composizioni degli architetti della secessione viennese, dall'altro l'uso di semicolonne e semiparaste doriche richiama la tradizione neoclassica italiana. L'architetto si relaziona con un lotto triangolare ed organizza il sistema di aule su due piani, lungo un corridoio che si affaccia su un cortile trapezoidale, concentrico al perimetro esterno dell'edificio. È evidente la grande capacità progettuale che caratterizza il Fichera nell'ideare le soluzioni d'angolo: taglia gli spigoli ai lati del prospetto principale con un piano a $45^{\circ}$ (fig. 7 ) per conferire un senso di continuità tra i prospetti ed inserisce un volume semicircolare nel vertice del triangolo isoscele su cui si imposta l'impianto planimetrico.

Per la particolare spazialità dell'edificio e dell'apparato architettonico e decorativo, che con un gioco di ombre dona plasticità ai prospetti, è stata scelta un'indagine di rilievo fotogrammetrico, atta a restituire la tridimensionalità dell'istituto. Dal confronto tra la documentazione d'archivio (foto d'epoca, dettagli dei decori e viste prospettiche del prospetto principale) ed i modelli 3D ottenuti è emersa, da un lato, la congruenza tra il progetto e lo stato di fatto e, dall'altro, l'esigenza di comunicare e far comprendere al visitatore museale la spazialità del luogo, in mancanza dell'elaborato planimetrico originale. 
Fig. 7. Foto d'epoca de prospetti e disegni di progetto dell'ingresso principle e del particolare dell'orologio nel cortile interno (Archivio Fichera).
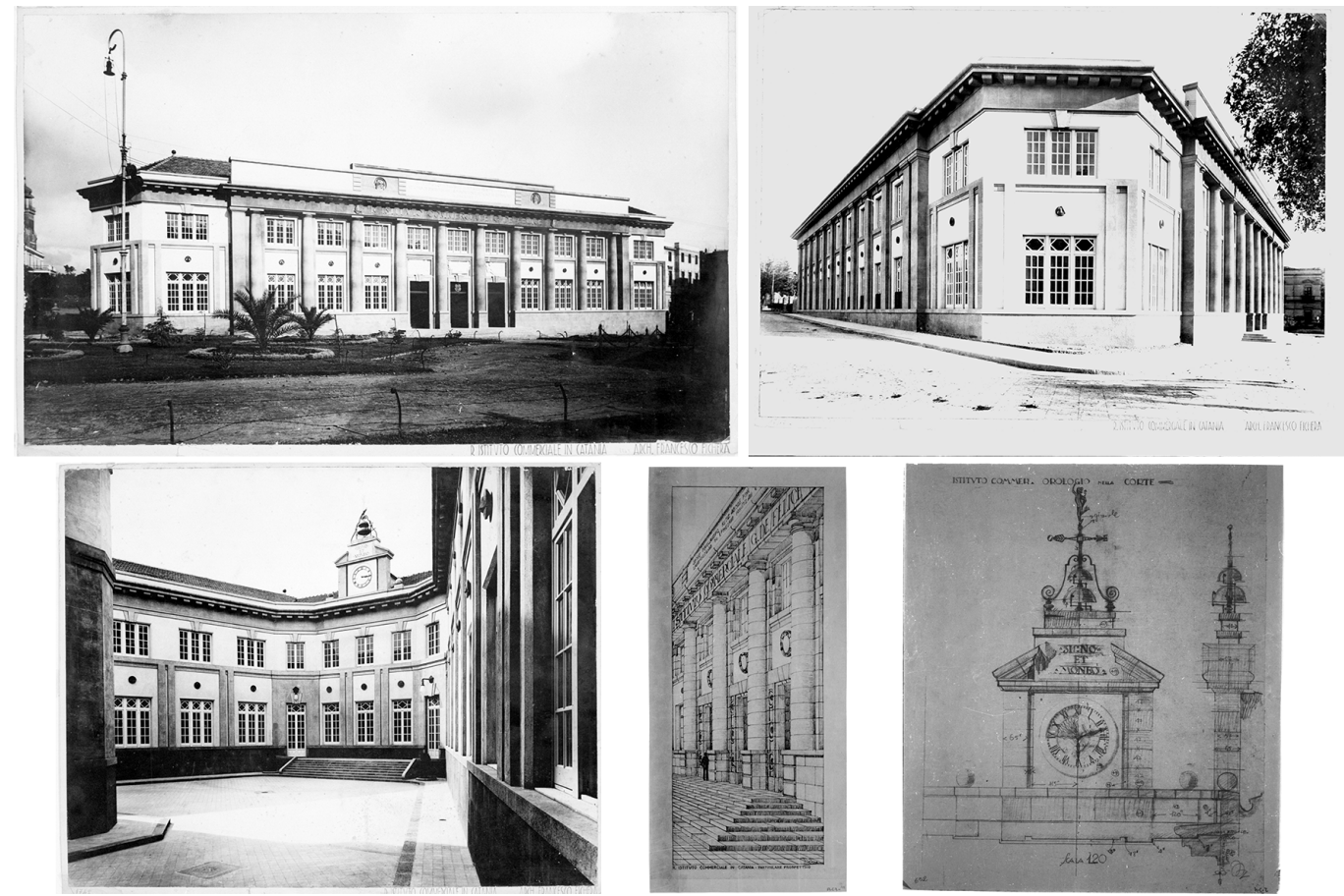

Per queste ragioni si è deciso di realizzare un'esperienza di simulazione virtuale basata sull'uso di 22 immagini panoramiche a 360 (fig. 8) [Aiello 2020, pp. I 37- I 58], ottenute con la fotocamera GoPro Fusion. La visita è stata progettata per essere fruibile sia sul web (via computer e smartphone) sia in modalità VR, utilizzando visualizzatori VR low-cost. L'utilizzo del software 3D Vista Virtual Tour Pro ha permesso di personalizzare l'esperienza inserendo elementi multimediali collegati a hotspot (testi, audio, video). Un hotspot permette, ad esempio, all'utente di visionare i disegni di archivio durante la visita virtuale e, quindi, di coglierne le peculiarità progettuali. L'obiettivo è, anche, quello di rendere possibile una visita virtuale a distanza all'interno di uno degli edifici più caratteristici progettati dal Fichera, non sempre facilmente accessibile a visite turistiche, in quanto sede scolastica.

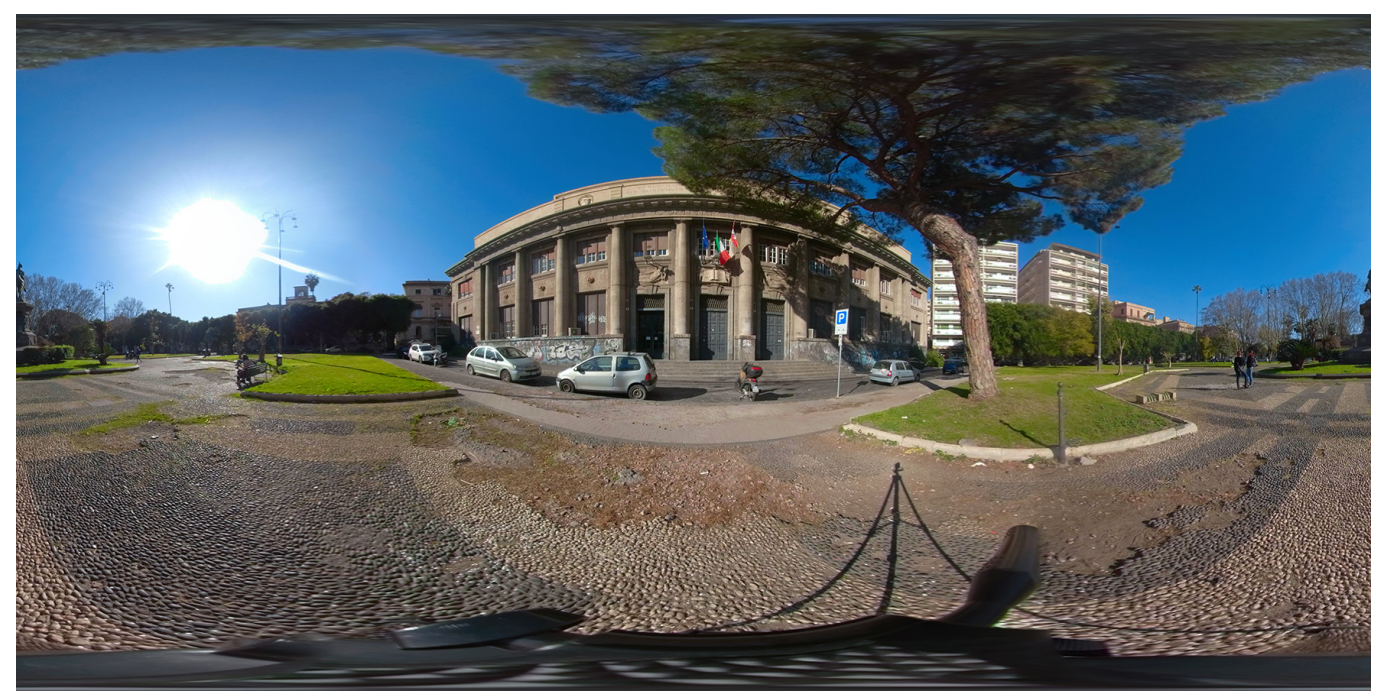




\section{Conclusioni e sviluppi futuri}

La ricerca condotta ha ottenuto come risultato il coinvolgimento dell'utenza in termini di interesse, affezione e appartenenza al patrimonio storico della città.

La sperimentazione di nuove forme strutturate di comunicazione della memoria, che affiancano e integrano la tradizionale comunicazione specialistica degli archivi, ha posto il visitatore e lo studioso al centro del percorso compiuto tra progetto e realizzazione. II visitatore, facendo uso di percorsi immersivi e interattivi, è fruitore virtuale del progetto. Di fatto, nella connessione tra progetto di archivio, rilievo e modello digitale, avviene quel processo di comprensione della spazialità dell'architettura e allo stesso tempo di educazione al rispetto dei documenti di archivio e del patrimonio architettonico. In questo modo si ricompone il legame tra la città e i documenti, tra le persone e il contesto territoriale e sociale, contribuendo alla costruzione di una nuova coscienza civile e culturale. L'archivio, attraverso l'esposizione museale si proietta all'esterno, connettendo la città con i documenti storici che sono depositari della storia del luogo e dell'identità urbana [3].

\section{Note}

[I] La CCA - Canadian Center for Architecture di Montreal (1979), il DAM - Deutsches Architektur Museum di Francoforte (1979), I'IFA - Institut Francais d'Architecture di Parigi ( 1980), la sezione per l'architettura del Getty Institute di Los Angeles (1984), il NAI - Netherlands Architecture Institute di Rotterdam ( 1988).

[2] Nel 1978 l'Accademia Nazionale di San Luca dà avvio a una sezione di architettura contemporanea; nel 1980 viene inaugurato il CSAC (Centro studi e archivio della comunicazione) dell'Università di Parma; nel 1987 nasce l'Archivio Progetti dell'Università luav di Venezia e nel 1989 l'Archivio del '900 del Mart; nel 2002 viene inaugurato il MAXXI, Museo nazionale delle Arti del XXI Secolo con un settore dedicato all'architettura del novecento.

[3] Mariateresa Galizia ha scritto i paragrafi:" Introduzione", "Francesco Fichera (Catania, I88I - 1950)", "Conclusioni e sviluppi futuri". Graziana D'Agostino ha scritto i paragrafi: "Metodologia", "Istituto Tecnico Commerciale De Felice (1926)". Raissa Garozzo ha scritto il paragrafo: "Palazzina della Società Elettrica (1913)". Federico Mario La Russa ha scritto il paragrafo: "Palazzo delle Poste (1919)".

\section{Riferimenti bibliografici}

Accardi Aldo R.D., Chiarenza Stefano, Inglisa Rosalinda, Scarpato Noemi (20 I6). Digital museums of the imagined architecture: an integrated approach to the definition of cultural heritage's knowledge paths. In DisegnareCon, n. I7, Vol 9, pp. I5. I- I5. I I.

Aiello Damiano, D'Agostino Graziana, Galizia Mariateresa (2020).Virtual Baroque: Digitization Experience of the Ecclesiastical Heritage in Acireale. In Bolognesi Cecilia Maria, Santagati Cettina (eds.). Impact of Industry 4.0 on Architecture and Cultural Heritage. Cham: Springer, pp. 137-158.

Antinucci Francesco (20।4). Comunicare nel museo. Roma: Editori Laterza.

Bonacini Elisa (2018). Partecipazione e co-creazione di valore culturale. \#iziTRAVELSicilia e i principi della Convenzione di Faro. In II Capitale Culturale. Studies on the Value of Cultural Heritage. Eum edizioni, num. I7, pp. 227-273.

Conte Sara, Rossi Michela (2019). II modello BIM per la valorizzazione dell'architettura moderna. II caso Olivetti. In Dienne. Building Information Modeling, Data \& Semantics, vol. 04/2019, pp. 16-26.

Ferrari Federico, Medici Marco (2017). The virtual experience for cultural heritage: methods and tools comparison for Geguti Palace in Kutaisi, Georgia. In Brusaporci Stefano (eds.). Proceedings of the International and Interdisciplinary Conference Immagini? Image and Imagination between Re-presentation, Communication, Education, and Psychology Brixen. Florence, nov. 27-28. Firenze: DIDA Press, Dipartimento di Architettura Università degli Studi di Firenze.

Galizia Mariateresa (2002). L'ambiente urbano di Catania nel '900: le architetture degli "anni '20". Roma: Gangemi Editore.

Garofalo Vincenza (20|4). Unbuilt: quattro progetti di Alberto Sartoris: ridisegno e lettura grafica. Roma: Aracne.

Giudilli Antonio (20।8). Public Engagement: le attività del SIMUS con valore educativo, culturale e di sviluppo per la società. In Simus Magazine: <http://www.simus.unisi.it/it/2018//2/21/public-engagement-le-attivita-del-simus-con-valore-educativoculturale-e-di-sviluppo-per-la-societa/>.

Giuva Linda, Vitali Stefano, Zanni Rosiello Isabella (2007). Il potere degli archivi. Usi del passato e difesa dei diritti nella società contemporanea. Milano: Mondadori.

Guccione Margherita (2009). Archivi e musei di architettura: atti della giornata di studio MAXXI Museo nazionale delle arti del XXI secolo. 2 I gennaio 2008. Roma: Gangemi Editore.

Guarrera Fabio (2017). Francesco Fichera: la modernità nella tradizione dell'architettura. Siracusa: LetteraVentidue. 
Guidi Gabriele, Micoli Laura Lorena, Gonizzi Sara, Rodriguez Navarro Pablo, Russo Michele (20।3). 3D digitizing a whole museum: A metadata centered workflow. In 2013 Digital Heritage International Congress (DigitalHeritage), pp. $307-310$.

Liggeri Domenico (20I5). La comunicazione di musei e archivi d'impresa. Metodologie dell'informazione e strategie mediatiche. Bergamo: Lubrina.

Luigini Alessandro, Panciroli Chiara (20।8). Ambienti digitali per l'educazione all'arte e al patrimonio. Milano: Franco Angeli.

Mandelli Elisa (2017). Esporre la memoria. Le immagini in movimento nel museo contemporaneo. Udine: Forum.

Palestini Caterina (2019). Digital Exploration in Archival Heritage. Research for the Knowledge, Use and Communication of Architecture Archives Through Digital Representation. In Luigini Alessandro (a cura di). Proceedings of the Ist International and Interdisciplinary Conference on Digital Environments for Education, Arts and Heritage. Cham: Springer International Publishing, pp. |47-I53.

Palombini Augusto (2012). Narrazione e virtualità: possibili prospettive per la comunicazione museale. In Digltalia, 20 I, VII/ I, pp. 9-22.

Parry Ross, Sawyer Andrew (2005). Space and the machine: adaptive museums, pervasive technology and the new gallery environment. In Macleod Suzanne. Reshaping Museum Space. Londra: Routledge, pp. 39-52.

Potenziani Marco, Callieri Marco, Dellepiane Matteo, Corsini Massimiliano, Ponchio Federico, Scopigno Roberto (20I5). 3DHOP: 3D Heritage Online Presenter. In Computers \& Graphics. Vol. 52/20 I5, pp. I29-I4I.

Salmini Claudia (20/4). Gli archivi tra comunicazione e rimozione. In Giuva Linda, Guercio Maria. Archivistica. Teorie, metodi, pratiche. Roma: Carocci.

Santagati Cettina, Galizia Mariateresa, Basso Alessandro, La Russa Federico Mario (20 I 8). Reshaping the Identity of University Museums:The Museo della Rappresentazione in Catania as Digital Innovation Hub for the Engagement of New Generations and the Development of the Territory. In EARTH 2018. Proceedings of the Ist International and Interdisciplinary Conference on Digital Environments for Education, Arts and Heritage, pp. 737-746.

Santagati Federica Maria Chiara (2017). II Museo della Rappresentazione dell'Università di Catania verso la riapertura. In Messina Luigi. Spazi espositivi della città di Catania. Patrimoni, problemi e nuove prospettive.Viagrande: Algra Editore, pp. 95 - I I6.

Scandurra Simona, Pulcrano Margherita, Cirillo Vincenzo, Campi Massimiliano, di Luggo Antonella, Zerlenga Ornella (20।8). Integrated survey procedures for the virtual reading and fruition of historical buildings. In The International Archives of the Photogrammetry, Remote Sensing and Spatial Information Sciences, XLII-2, pp. I 037- I 044.

Solima Ludovico (2007). Nuove tecnologie della comunicazione. In Economia della Cultura, 3/2007, pp. 365-376.

Unali Maurizio (2006). Lo spazio digitale dell'architettura italiana: idee, ricerche, scuole, mappa. Roma: Kappa.

Unali Maurizio (20 I4). Atlante dell'abitare virtuale: il disegno della città virtuale, fra ricerca e didattica. Roma: Gangemi.

UNIMORE (2019). Rete dei Musei Universitari Italiani: <http:/www.retemuseiuniversitari.unimore.it/site/home.html>.

Valacchi Federico (2006). Archivi storici: per una cultura della gestione. In Culture del testo e del documento, 19/200, pp. 19-36.

\section{Autori}

Mariateresa Galizia, Università degli Studi di Catania, mgalizia@dau.unict.it

Graziana D’Agostino, Università degli Studi di Catania, graziana.dagostino@unict.it

Raissa Garozzo, Università degli Studi di Catania, raissa.garozzo@unict.it

Federico Mario La Russa, Università degli Studi di Catania, federico.larussa@phd.unict.it

Per citare questo capitolo: Galizia Mariateresa, D'Agostino Graziana, Garozzo Raissa, La Russa Federico Mario (2020). Connessioni tra museo/ archivi e città: strategie digitali per la valorizzazione e comunicazione del fondo Fichera del Museo della Rappresentazione/Museum/Archives and city connections: digital strategies for the valorization and divulgation of the Fichera Archive of the Museo della Rappresentazione. In Arena A., Arena M., Brandolino R.G., Colistra D., Ginex G., Mediati D., Nucifora S., Raffa P. (a cura di). Connettere. Un disegno per annodare e tessere. Att del $42^{\circ}$ Convegno Internazionale dei Docenti delle Discipline della Rappresentazione/Connecting. Drawing for weaving relationships. Proceedings of the 42th International Conference of Representation Disciplines Teachers. Milano: FrancoAngeli, pp. 2224-2241. 


\title{
Museum/Archives and City Connections: Digital Strategies for the Valorization and Divulgation of the Fichera Archive of the Museo della Rappresentazione
}

\author{
Mariateresa Galizia \\ Graziana D'Agostino \\ Raissa Garozzo \\ Federico Mario La Russa
}

Abstract

The study proposes the experience conducted at the Museo Della Rappresentazione (MuRa) of Dicar, belonging to the Sistema Museale d'Ateneo of Catania. This museum keeps and exhibits the projects of some Sicilian architects who contributed to define the local architectural and urban identity. MuRa is both an archive for scholars and a museum that exhibits some of the pieces of the collections it holds. These technical documents preserve the memory of the past way of designing and need new tools and strategies to spread the documentary heritage and to explain it to non-experts. That is the reason why MuRa is currently a place for experimentation and research of new languages and strategies in cultural heritage promotion. It also plays a key educational role in promoting affection and identification with places. The experimentation was carried out on some projects included in the fund of the architect Francesco Fichera (I88I-1950) from Catania and produced digital models obtained through the integration and/or comparison between built information, archive design and survey data. The digital products also allow the virtual and immersive experience of the architecture exhibited at MuRa, attracting the interest of the wide range of visitors to the museum. The technical material elaborated also integrates the documentation kept, and for this reason it should also be cataloged.

Keywords

Documentation, Representation, Virtuality, Digital Survey, Accessibility.
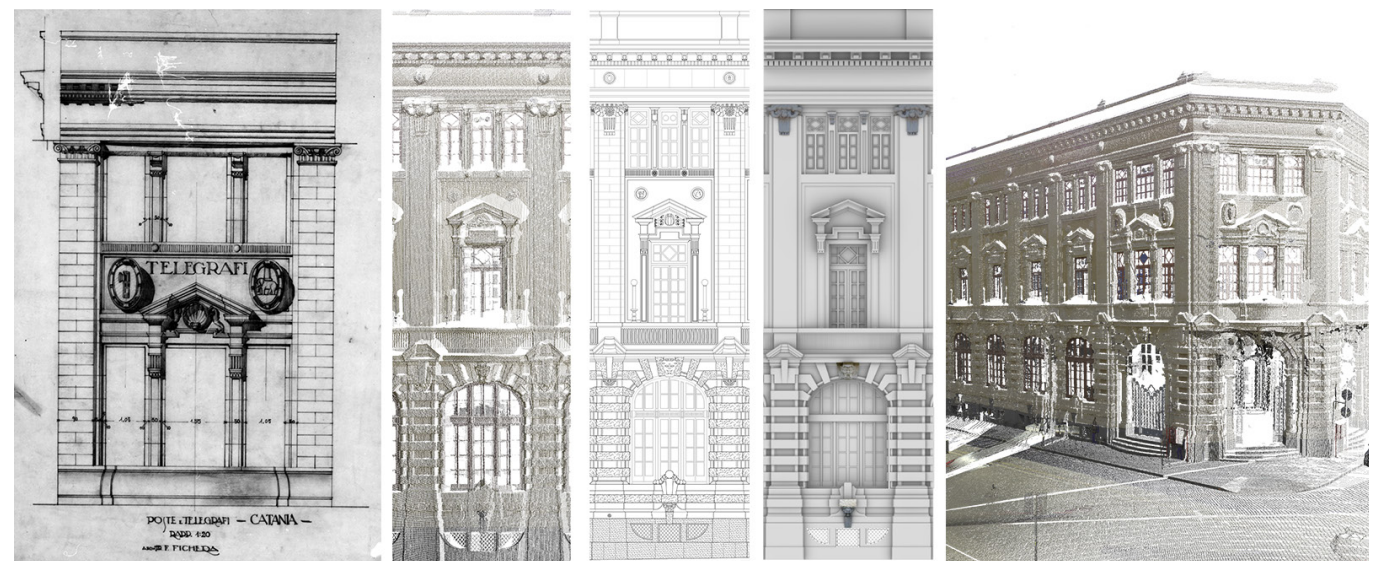


\section{Introduction}

The document on museums, published by UNESCO in 1984, focuses on the preservation of the original documentation of the cultural heritage and archive museums. Among these ones there is the iconographic heritage of architectural projects, whose interest will give rise to institutions aimed at the study of original documents for the preservation of the historical memory of places [I]. Italy participated actively and with interest in the safeguarding of historical-archival heritage, setting up programs for the collection, conservation and promotion of archives [2]. Private centres and foundations were created and, at the same time, libraries and universities also became places for the conservation and consultation of documents. One of them was the Departmental Institute of Architecture and Urban Planning of the ex-Faculty of Engineering of Catania, now called Department of Civil Engineering and Architecture (University of Catania). In 1976, the heirs of the architect Francesco Fichera from Catania donated his project archive to the Department above mentioned. The donation counted about 1600 original drawings, executed with different techniques pencil, pastels, ink, watercolour - and even in heliographic copy. Thanks to the Catania-Lecce project of 1997, this collection and other ones were transferred to the Museo della Rappresentazione, part of the Department and, since 20I5, also part of the University's Museum System of Catania.The museum is both an archive open to scholars and a gallery where the highly technical documentary material of the funds owned is exhibited. The mission of the Museum, in addition to the need to preserve, safeguard and facilitate access to its archival heritage, is the commitment to cultural education and respect for places through the research of new forms of communication of the cultural heritage. The aim of the article is to discuss the results of the experimentation carried out on the museum communication of three projects of public architectures, realized in Catania by the architect Francesco Fichera in the early 1900s. The main target is to communicate in a clear and easy-to-understand way the poetics of the designer, characterized by tradition and innovation, not only to the people working in the field but also to the larger public. Indeed, the incompleteness of the archive documentation and the small amount of exhibited works (for each project) constitutes a limit to the understanding of the stylistic-formal and geometric-spatial characteristics of the projects within the museum's exhibition. 3D models have been created for the virtual fruition of the exhibited architectures in an effort to make the comprehension of these ones clear and immediate. This has been achieved through a process of integration of the project's documentation and digital survey data.

\section{Methodology}

The methodology adopted has involved the experimentation of innovative strategies of documentation and communication that, through virtual and immersive experiences, would make the projects of the Fichera archive more comprehensible. For this reason, we proceeded with the expansion and implementation of the existing graphic documentation of some public architecture spaces created by the Sicilian designer. Three macro-phases are identified:

- documentation: interpretation and critical analysis of the project drawings conserved in the archive, to understand the graphic material lack and the possible variations in process and to investigate the design process;

- representation: integrated digital survey (Laser Scanner and Structure from Motion - SfM) of the case studies to obtain both three-dimensional reconstructions and revised two-dimensional elaborations;

- virtuality: use of low-cost VR technologies for the valorisation and transmission of the cultural heritage memory and historical identity.

First, the historical-documental survey was carried out, consulting the archive material, such as the existing cataloguing sheets - which comply with the ICCD requirements on the catalogue of BB.CC. - and the project drawings present in paper and digital format, in order to 
make a critical interpretation of the project, in relation to the building constructed. Where the material was lacking, survey campaigns were carried out using Laser Scanner, model RTC360 of Leica Geosystem, and SfM methodology, with a Canon Eos I200D camera, in relation to the geometric/spatial characteristics of the buildings. The survey elaborations allow users - who visit the Museum's spaces where the archival drawings are shown - to virtually enjoy some of the architecture investigated areas.

To involve users in a cognitive and interactive virtual tour, two different techniques have been tested: one in which the user, accessing the online platform Sketchfab and using lowcost virtual reality viewers, is inside a cloud of points where he can move freely and perceive the places spatiality, often inaccessible to the public [Santagati 2018, pp. 737-746]; the other through the use of spherical images [Ferrari 2017, pp. 27, 28; Scandurra 2018, pp. 10371044]. This approach makes the immersive experience easier and more immediate because raster content requires less computational resources and is easy to use on mobile devices. At the same time, the museum visitor has the possibility to simply view the 3D restitution on their mobile device.

\section{Fichera and public buildings: between tradition and innovation}

\section{Francesco Fichera (Catania, I881-1950)}

Francesco Fichera is one of the main exponents of Sicilian architectural culture in the first half of the twentieth century. Graduated from the Royal School of Application in Rome in 1905, he obtained a diploma in Architecture at the Academy of Fine Arts in Palermo and became lecturer in 1909. Since 1913, he is professor of Design of ornate and elementary architecture at the first nucleus of the Faculty of Engineering of Catania. Considered one of the greatest figures of Modernism, he designed numerous residential and public works [Guarrera 2017]. He experimented with formal solutions varying from Eclecticism to Liberty, Deco and Rationalism. In public architecture, Fichera mediates between the need for a representative style and the new culture, re-proposing classic styles combined with new compositional solutions [Galizia 2002].This is in accordance with the principles of the time according to which government architectures should assume a symbolic role for the city and to be expression of a political regime looking for a large consensus. In this work, three architectures realized in Catania have been investigated among the public works that can represent the architect's design path: the building of the Società Elettrica, the Palazzo delle Poste, the Istituto Tecnico Commerciale De Felice (fig. I).

Fig. I. On the left the Palazzina Enel, in the centre the Palazzo delle Poste, on the right the Istituto
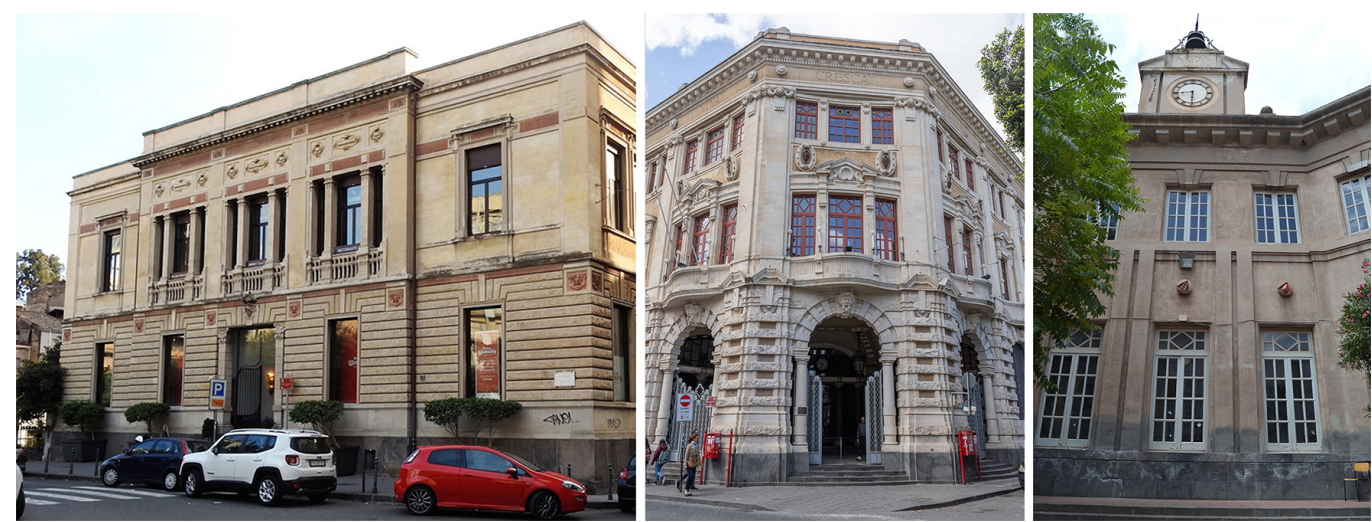

Palazzina della Società Elettrica (19/3)

The Palazzina per la fornitura di Energia Elettrica is a linear and compact building on three levels, characterized by a sober and innovative reinterpretation of the Art Deco style.

The Secessionist-inspired façade is characterized by some features: the slightly overhanging pilasters and string courses, the chromatic variations of decorative terracotta tiles bearing the Trinacria symbol on light-coloured plaster, the horizontal bands of rough ashlar plaster, 
Fig. 2. On the left, points cloud of the outside; o the right, points cloud of the monumental staircase
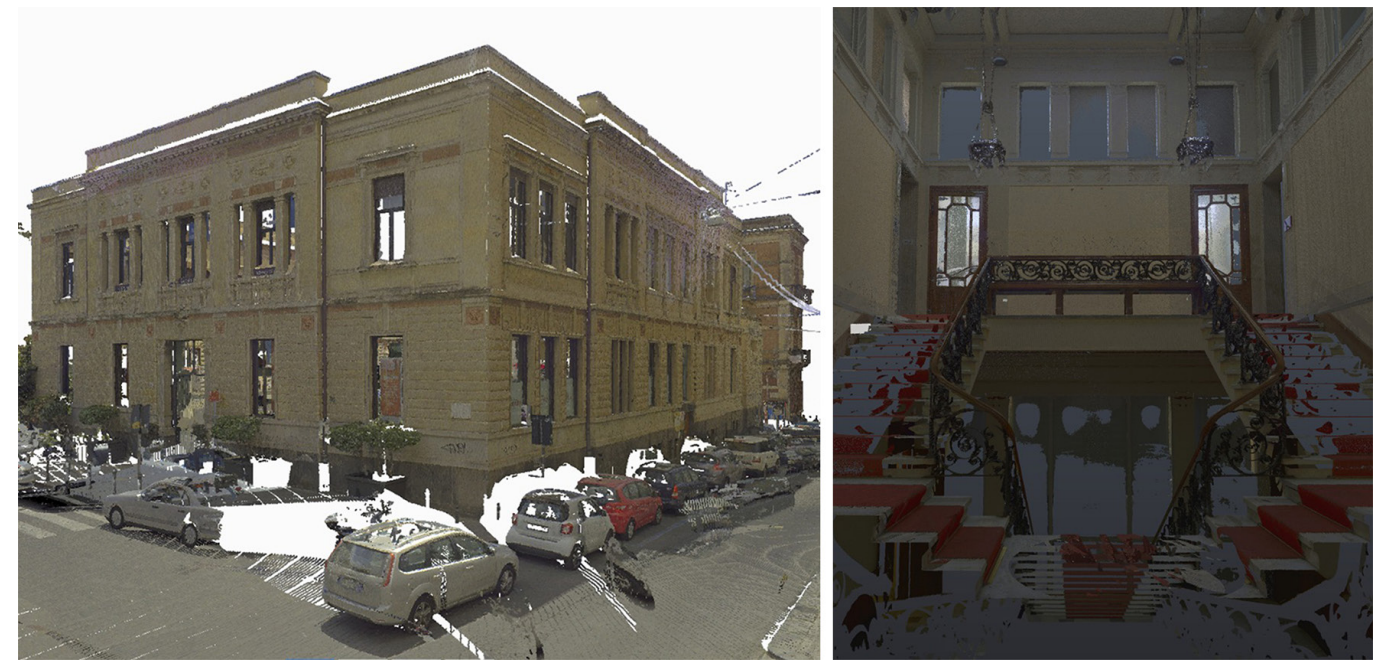

which mark the ground floor. The building consists of three levels: the basement, which in its original configuration housed the technical rooms, the ground floor serving the public and the last level for the administration. The entrance hall led to the large central hall, naturally lit by a wrought iron skylight. The core of the entire building is the monumental pincer staircase decorated with a fine cast-iron railing with spirals on Art Nouveau motifs. The building has been modified due to the change of use: the entrance and the hall are currently a commercial area, the rest of the building is private. A partition has been added to separate the spaces, hiding the monumental staircase and not allowing an overall view into the building. As a result of the examination of the documents that are part of the Fichera archive and the comparison of these with the actual state of affairs, it was necessary to create current supplementary content. Some deviations from the original design idea could be identified, such as the different formal solutions of the windows along the main elevation (fig. 3).
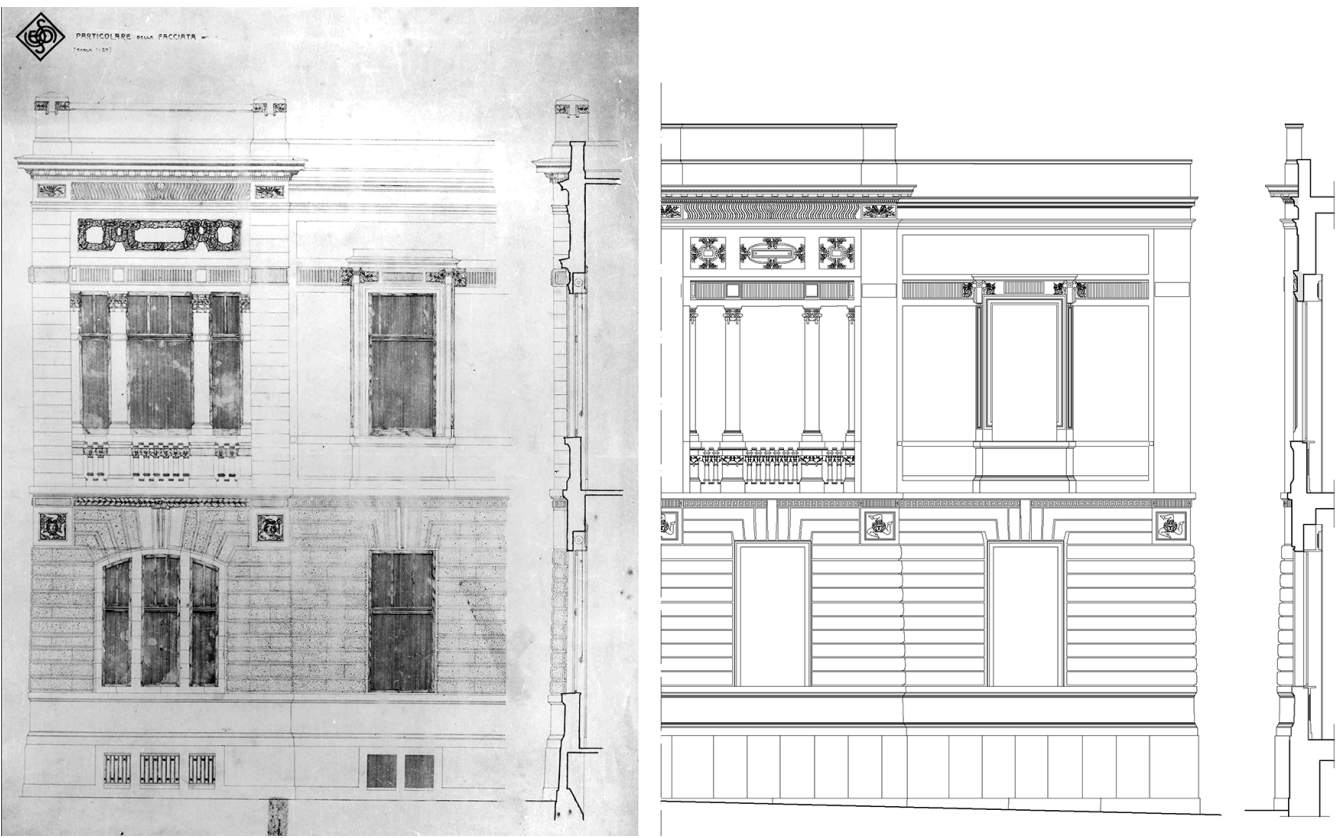
Fig. 4. Documents of the Palazzo delle Poste (Fichera Archive), from eft to right: plan staircase scale 1:200 and 1:20, construction detal parapet.
To overcome the lack of documentation relating to the emblematic monumental staircase and allow an overview of the not-fully-usable spaces of the building, the secondary entrance, the staircase, the external area at the skylight and the elevations were acquired three-dimensionally using laser scanning methodology (fig. 2). Multi-image photogrammetry, instead, was used for surveying some of the period furnishings. This approach has allowed the creation of two and three-dimensional objects, to reconstruct a complete documentation of the building and communicate the design idea to non-experts, also through a virtual fruition of the spaces.
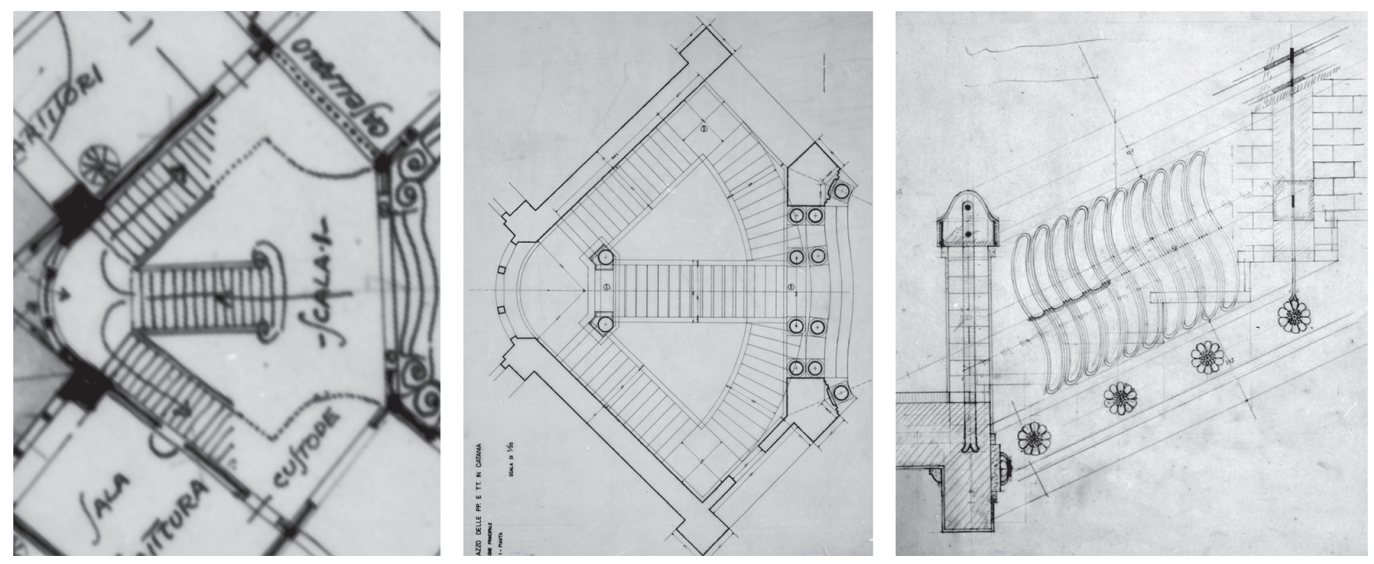

Palazzo delle Poste (1919)

The Palazzo delle Poste, built in 1929, consists of three levels and is characterized by facades in lava and lime stones. These ones define convex spans marked by pilasters of giant order. The building occupies a header city block overlooking via Etnea, via della Posta and via Sant'Euplio. The baroque exteriors are integrated with modernist solutions in the interior pathways.

In axis with the main entrance, you can access the staircase for the public, interesting for the triangular plan and the development of the ramps. It presents unique artefacts such as the two columns that support the intermediate landings in Art Nouveau style. Currently the staircase is not accessible to the public.

The documents in the Fichera archive related to this staircase consist of plans on a scale of 1:200 (relating to the first design hypothesis) and the subsequent executive drawings at 20 (a plan and a construction section of the parapet) (fig. 4). The absence of significant elevations and/or sections and the inaccessibility of this environment have prompted the adoption of the architectural survey methodology for the purpose of verification (with respect to the documents) and divulgation.

The survey has been conducted by integrating direct and instrumental methodologies (laser scanning). The products were compared with the available executive drawings, investigating possible variations in the course of the work. After that has been realized a vertical section to represent (in coherence with the archival documents) the spatial development of the staircase (fig. 5). The particular spatiality due to the arrival ramps to the landings (with curvilinear axes) and the plasticity of the decorations, hardly show elements in orthographic view, making it difficult to read the space and the architectural language created by the designer. For this reason, the point cloud obtained from the instrumental survey was imported into CloudCompare for an optimization that is functional to the online exploration of the model in virtual reality. This is possible thanks to the online platform Sketchfab.com, which allows to easily incorporate 3D content on websites and other digital platforms. This platform is already used by museums, such as the British Museum. Other solutions such as 3DHop and Europeana have been evaluated for future developments in relation to more complex and specific content. Through Sketchfab.com it is therefore possible to explore the model in virtual reality (fig. 6) either through low cost VR viewers (such as Google Cardboard) or with more performing VR viewers (such as Oculus Rift). 
Fig. 5. From left to right: vertical section of the staircase through the main axis and photos of the entrance and decorated columns.

Fig. 6.VR settings interface on the Sketchfab online platform.
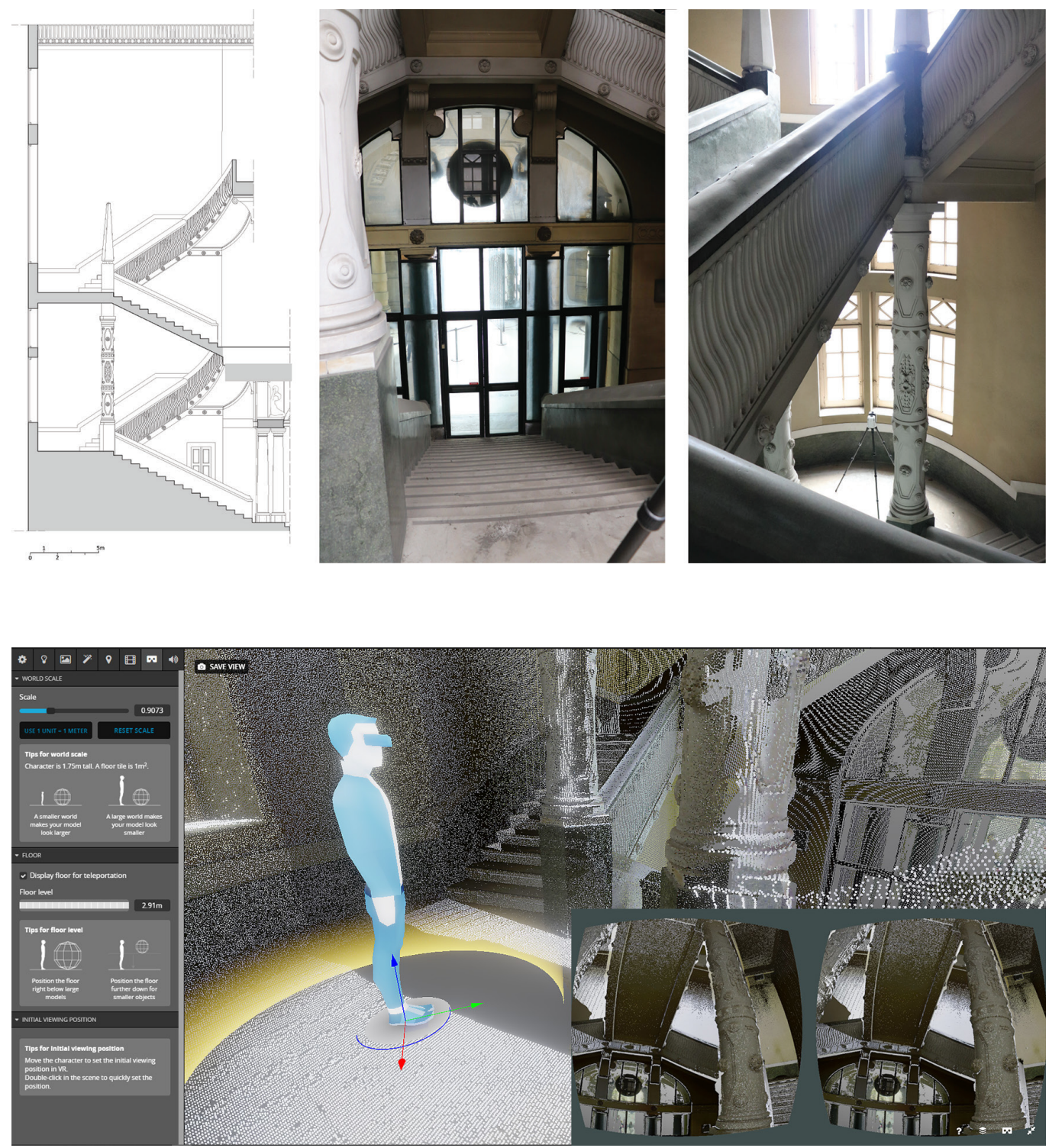

Istituto Tecnico Commerciale De Felice (1926)

The architectural solutions adopted in the educational institution project represent the recurring themes of the Fichera's modus operandi. If on the one hand the tripartite windows of the external facades recall the compositions of the Viennese secession architects, on the other the use of Doric semi-columns and semi-pilaster recalls the Italian neoclassical tradition. The architect designed the building on a triangular lot and organized the classrooms system on two floors, along a corridor overlooking a trapezoidal courtyard, concentric to the external perimeter of the building. It is obvious the architect great design ability in the corner solutions design: he cuts the corners at the sides of the main facade with a $45^{\circ}$ plane (fig. 7) to give a sense of continuity between the facades and inserts a semi-circular volume in the vertex of the isosceles triangle on which the plan is set.

For the particular spatiality of the building and of the architectural and decorative apparatus, that thanks to a shadows play gives plasticity to the façades, a photogrammetric survey was chosen in order to recreate the three-dimensionality of the institute. Thanks to the comparison between the archival documentation (historical photographs, details of the decorations and perspective views of the main facade) and the 3D models obtained, has been possible to check the correspondence between the original project and the actual building. This 
Fig. 7. Historical photographs of the facades and project drawings of the main entrance and of the clock detail in the inner courtyard (Fichera Archive).
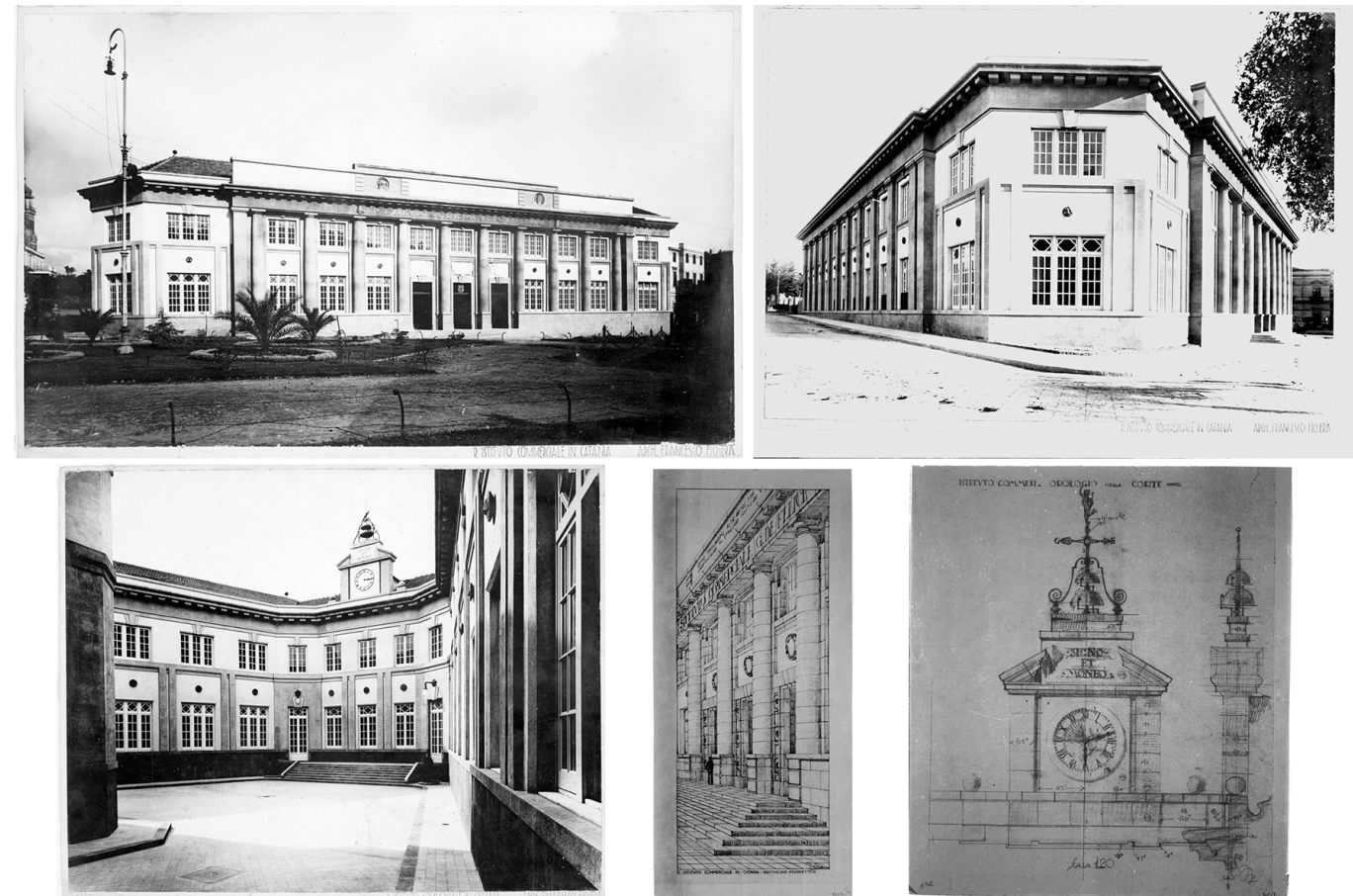

operation has created the need to better communicate to the museum visitor the spatiality of the place, in the absence of original design documents.

For these reasons it was decided to create a virtual simulation experience based on the use of $22360^{\circ}$ panoramic images (fig. 8) [Aiello 2020, pp I37-I58], obtained with the GoPro Fusion camera. The tour is designed to be accessible both on the web (by computer and smartphone) and in VR mode, using low-cost VR viewers. The use of the 3D Vista Virtual Tour Pro software allowed to customize the experience by inserting multimedia elements connected to hotspots (text, audio, video). A hotspot, for example, allows the user to view the archive drawings during the virtual tour and, therefore, to understand their design characteristics. The aim is also to make possible a virtual tour inside one of the most characteristic buildings designed by Fichera, which is not always easily accessible for tourist visits, as it is an educational institution.

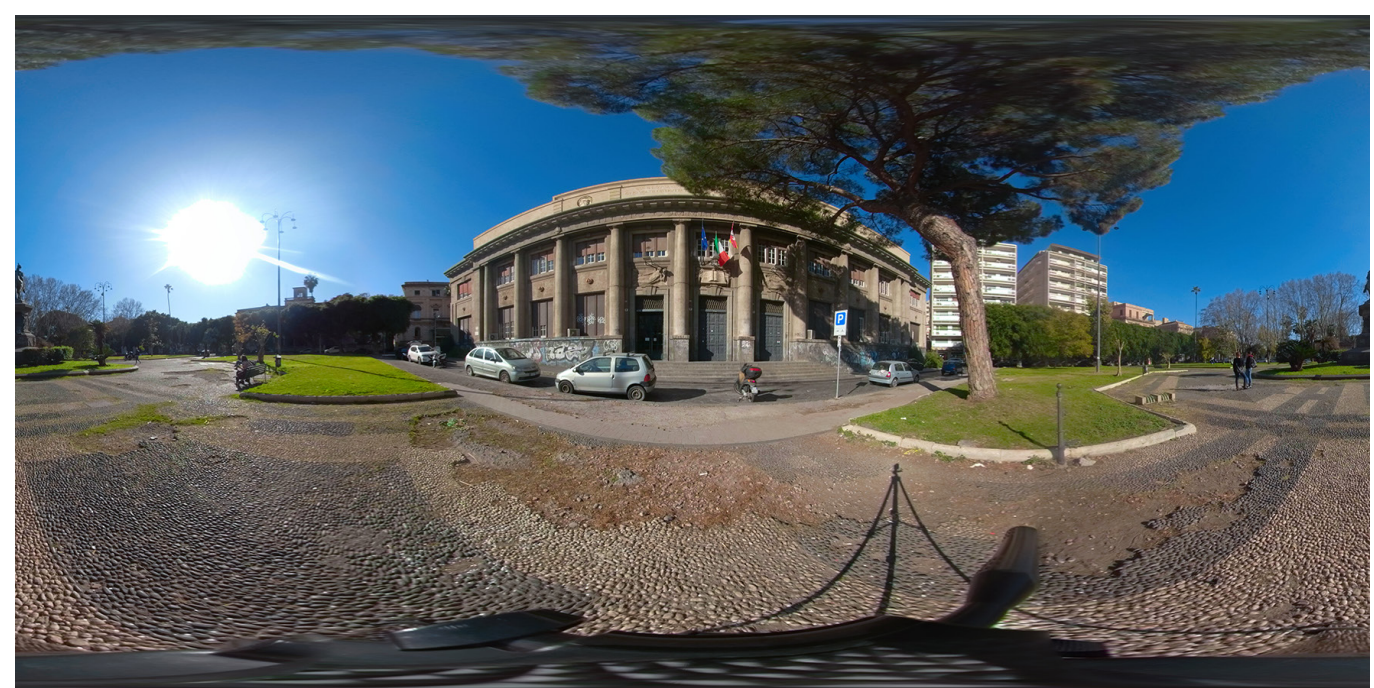




\section{Conclusions and future developments}

The research aimed at involving users in terms of interest, affection and belonging to the city historical heritage. New strategies in the communication of memory, which combine and integrate the traditional way to inform of archives, involve visitors and scholars in the flow that starts from the project and ends with the final realization. Using immersive and interactive paths, the visitors become virtual users of the project. The connection between archive project, survey, and digital model, leads the process of understanding the architecture and, at the same time, of education in respecting archive documents and architectural heritage. In this way the link between the city and the documents, between people and the territorial and social context is restored, contributing to the construction of a new civil and cultural awareness. The archive, through the museum exhibition, proposes itself outside, connecting the city with the historical documents that are repositories of the history and urban identity [3].

\section{Notes}

[I]The CCA - Canadian Center for Architecture in Montreal (1979), the DAM - Deutsches Architektur Museum in Frankfurt (1979), the IFA - Institut Francais d'Architecture in Paris (1980), the architecture section of the Getty Institute in Los Angeles (1984), the NAl - Netherlands Architecture Institute in Rotterdam (1988).

[2] In 1978 the Accademia Nazionale di San Luca established a section on contemporary architecture; in 1980 the CSAC (Centro studi e archivio della comunicazione) of the University of Parma was inaugurated; in 1987 the Project Archive of the luav University of Venice was founded and in 1989 the Archivio del '900 del Mart was opened; in 2002 the MAXXI, the National Museum of XXI Century Arts, was inaugurated with a section dedicated to twentieth century architecture.

[3] Mariateresa Galizia wrote the paragraphs: "Introduction”," "Francesco Fichera (Catania, I 88 I - I950)", "Conclusioni e sviluppi futuri". Graziana D'Agostino wrote the paragraphs: "Methodology", "Istituto Tecnico Commerciale De Felice" (1926). Raissa Garozzo wrote the paragraph: "Palazzina della Società Elettrica (1913)". Federico Mario La Russa wrote the paragraph: "Palazzo delle Poste (1919)".

\section{References}

Accardi Aldo R.D., Chiarenza Stefano, Inglisa Rosalinda, Scarpato Noemi (20 I6). Digital museums of the imagined architecture: an integrated approach to the definition of cultural heritage's knowledge paths. In DisegnareCon, n. I7, Vol 9, pp. I 5. I - I5. I I.

Aiello Damiano, D'Agostino Graziana, Galizia Mariateresa (2020).Virtual Baroque: Digitization Experience of the Ecclesiastical Heritage in Acireale. In Bolognesi Cecilia Maria, Santagati Cettina (eds.). Impact of Industry 4.0 on Architecture and Cultural Heritage. Cham: Springer, pp. 137-158.

Antinucci Francesco (20।4). Comunicare nel museo. Roma: Editori Laterza.

Bonacini Elisa (2018). Partecipazione e co-creazione di valore culturale. \#iziTRAVELSicilia e i principi della Convenzione di Faro. In II Capitale Culturale. Studies on the Value of Cultural Heritage. Eum edizioni, num. I7, pp. 227-273.

Conte Sara, Rossi Michela (2019). II modello BIM per la valorizzazione dell'architettura moderna. II caso Olivetti. In Dienne. Building Information Modeling, Data \& Semantics, vol. 04/2019, pp. I6-26.

Ferrari Federico, Medici Marco (2017). The virtual experience for cultural heritage: methods and tools comparison for Geguti Palace in Kutaisi, Georgia. In Brusaporci Stefano (eds.). Proceedings of the International and Interdisciplinary Conference Immagini? Image and Imagination between Re-presentation, Communication, Education, and Psychology Brixen. Florence, nov. 27-28. Firenze: DIDA Press, Dipartimento di Architettura Università degli Studi di Firenze.

Galizia Mariateresa (2002). L'ambiente urbano di Catania nel '900: le architetture degli "anni '20". Roma: Gangemi Editore.

Garofalo Vincenza (20|4). Unbuilt: quattro progetti di Alberto Sartoris: ridisegno e lettura grafica. Roma: Aracne.

Giudilli Antonio (20।8). Public Engagement: le attività del SIMUS con valore educativo, culturale e di sviluppo per la società. In Simus Magazine: <http://www.simus.unisi.it/it/2018//2/21/public-engagement-le-attivita-del-simus-con-valore-educativoculturale-e-di-sviluppo-per-la-societa/>.

Giuva Linda, Vitali Stefano, Zanni Rosiello Isabella (2007). Il potere degli archivi. Usi del passato e difesa dei diritti nella società contemporanea. Milano: Mondadori.

Guccione Margherita (2009). Archivi e musei di architettura: atti della giornata di studio MAXXI Museo nazionale delle arti del XXI secolo. 2 I gennaio 2008. Roma: Gangemi Editore.

Guarrera Fabio (20 I7). Francesco Fichera: la modernità nella tradizione dell'architettura. Siracusa: LetteraVentidue. 
Guidi Gabriele, Micoli Laura Lorena, Gonizzi Sara, Rodriguez Navarro Pablo, Russo Michele (20।3). 3D digitizing a whole museum: A metadata centered workflow. In 2013 Digital Heritage International Congress (DigitalHeritage), pp. $307-310$.

Liggeri Domenico (20I5). La comunicazione di musei e archivi d'impresa. Metodologie dell'informazione e strategie mediatiche. Bergamo: Lubrina.

Luigini Alessandro, Panciroli Chiara (20।8). Ambienti digitali per l'educazione all'arte e al patrimonio. Milano: Franco Angeli.

Mandelli Elisa (2017). Esporre la memoria. Le immagini in movimento nel museo contemporaneo. Udine: Forum.

Palestini Caterina (2019). Digital Exploration in Archival Heritage. Research for the Knowledge, Use and Communication of Architecture Archives Through Digital Representation. In Luigini Alessandro (a cura di). Proceedings of the Ist International and Interdisciplinary Conference on Digital Environments for Education, Arts and Heritage. Cham: Springer International Publishing, pp. |47-I53.

Palombini Augusto (2012). Narrazione e virtualità: possibili prospettive per la comunicazione museale. In Digltalia, 20 I, VII/ I, pp. 9-22.

Parry Ross, Sawyer Andrew (2005). Space and the machine: adaptive museums, pervasive technology and the new gallery environment. In Macleod Suzanne. Reshaping Museum Space. Londra: Routledge, pp. 39-52.

Potenziani Marco, Callieri Marco, Dellepiane Matteo, Corsini Massimiliano, Ponchio Federico, Scopigno Roberto (20I5). 3DHOP: 3D Heritage Online Presenter. In Computers \& Graphics. Vol. 52/20 I5, pp. I29-I4I.

Salmini Claudia (20/4). Gli archivi tra comunicazione e rimozione. In Giuva Linda, Guercio Maria. Archivistica. Teorie, metodi, pratiche. Roma: Carocci.

Santagati Cettina, Galizia Mariateresa, Basso Alessandro, La Russa Federico Mario (20 I 8). Reshaping the Identity of University Museums:The Museo della Rappresentazione in Catania as Digital Innovation Hub for the Engagement of New Generations and the Development of the Territory. In EARTH 2018. Proceedings of the Ist International and Interdisciplinary Conference on Digital Environments for Education, Arts and Heritage, pp. 737-746.

Santagati Federica Maria Chiara (2017). II Museo della Rappresentazione dell'Università di Catania verso la riapertura. In Messina Luigi. Spazi espositivi della città di Catania. Patrimoni, problemi e nuove prospettive.Viagrande: Algra Editore, pp. 95 - I I6.

Scandurra Simona, Pulcrano Margherita, Cirillo Vincenzo, Campi Massimiliano, di Luggo Antonella, Zerlenga Ornella (20।8). Integrated survey procedures for the virtual reading and fruition of historical buildings. In The International Archives of the Photogrammetry, Remote Sensing and Spatial Information Sciences, XLII-2, pp. I 037- I 044.

Solima Ludovico (2007). Nuove tecnologie della comunicazione. In Economia della Cultura, 3/2007, pp. 365-376.

Unali Maurizio (2006). Lo spazio digitale dell'architettura italiana: idee, ricerche, scuole, mappa. Roma: Kappa.

Unali Maurizio (20 I4). Atlante dell'abitare virtuale: il disegno della città virtuale, fra ricerca e didattica. Roma: Gangemi.

UNIMORE (2019). Rete dei Musei Universitari Italiani: <http:/www.retemuseiuniversitari.unimore.it/site/home.html>.

Valacchi Federico (2006). Archivi storici: per una cultura della gestione. In Culture del testo e del documento, 19/200, pp. 19-36.

\section{Authors}

Mariateresa Galizia, Università degli Studi di Catania, mgalizia@dau.unict.it

Graziana D’Agostino, Università degli Studi di Catania, graziana.dagostino@unict.it

Raissa Garozzo, Università degli Studi di Catania, raissa.garozzo@unict.it

Federico Mario La Russa, Università degli Studi di Catania, federico.larussa@phd.unict.it

To cite this chapter. Galizia Mariateresa, D'Agostino Graziana, Garozzo Raissa, La Russa Federico Mario (2020). Connessioni tra museo/archivi e città: strategie digitali per la valorizzazione e comunicazione del fondo Fichera del Museo della Rappresentazione/Museum/Archives and city connections: digital strategies for the valorization and divulgation of the Fichera Archive of the Museo della Rappresentazione. In Arena A., Arena M., Brandolino R.G., Colistra D., Ginex G., Mediati D., Nucifora S., Raffa P. (a cura di). Connettere. Un disegno per annodare e tessere. Atti del $42^{\circ}$ Convegno Internazionale dei Docenti delle Discipline della Rappresentazione/Connecting. Drawing for weaving relationships. Proceedings of the 42th International Conference of Representation Disciplines Teachers. Milano: FrancoAngeli, pp. 2224-224l. 